\title{
Effect of Magnesium Sulphate and Copper Sulphate Foliar Application on Wheat under Sandy Soil Conditions
}

\author{
El-Met. A. El-Metwally, S.A. Safina, F.E. Abdalla* and Sara \\ S. A. EI-Sawy ${ }^{*}$ \\ Agronomy Deptartment, Facult of Agriculture, Cairo University and \\ *Fertilization Technology Deptartment, National Research Centre \\ (NRC), Giza, Egypt.
}

\begin{abstract}
7 FO FIELD experiments were conducted at Ismailia Exp. Sta., Agric. Res. Centre, Egypt, in 2007/2008 and 2008/2009 seasons to study the effect of foliar application of copper sulphate $\left(\mathrm{CuSO}_{4}\right)$ and magnesium sulphate $(\mathrm{Mg})$ on growth, yield and grain quality of wheat (Triticum aestivum L. cv. Sakha 94) under sandy soil conditions. The results indicated that foliar application of $6.72 \mathrm{~kg} \mathrm{MgSO}+1.68 \mathrm{~kg}$ $\mathrm{CuSO}_{4} / \mathrm{fed}$ produced the highest values of growth attributes such as plant height, tillers $/ \mathrm{m}^{2}$, flag leaf area, chlorophyll contents and dry matter $/ \mathrm{m}^{2}$. The highest positive significant effects on spike $/ \mathrm{m}^{2}$, spike length, no. of grains/spike, grains weight/spike, 1000-grains weight, grain yield/fed and straw yield/fed were achieved by spraying copper sulphate and magnesium sulphate treatments. The highest increment in grain yield was obtained by spraying wheat plants by $1.68 \mathrm{~kg}$ $\mathrm{CuSO}_{4} / \mathrm{fed}$. Results also showed that the most of both macro and micronutrients content in wheat shoot increased markedly due to spraying wheat plants with $6.72 \mathrm{~kg} \mathrm{MgSO}_{4}+1.68 \mathrm{~kg} \mathrm{CuSO}_{4} / \mathrm{fed}$. On the other hand, the highest wheat grains content of protein, $\mathrm{N}, \mathrm{Mg}, \mathrm{Cu}$ and $\mathrm{Zn}$ contents $(15.45 \%, 2.65 \%, 0.35 \%, 7.90 \mathrm{ppm}$ and $54.40 \mathrm{ppm}$, respectively) were achieved with spraying wheat plants by $6.72 \mathrm{~kg}$ $\mathrm{MgSO}_{4}+1.68 \mathrm{~kg} \mathrm{CuSO} / / \mathrm{fed}$. However, spraying wheat plants with $0.84 \mathrm{~kg} \mathrm{CuSO} / \mathrm{fed}$ gave the highest grain carbohydrate percentage $(69.33 \%)$. Spraying wheat plants with $6.72 \mathrm{~kg} \mathrm{MgSO}_{4}+1.68 \mathrm{~kg}$ $\mathrm{CuSO}_{4} / \mathrm{fed}$ gave the highest magnesium, copper and $\mathrm{Zn}$ content $(0.28 \%$, $3.80 \mathrm{ppm}$ and $46.20 \mathrm{ppm}$, respectively) in wheat straw as compared with unsprayed plants. The correlation coefficient between wheat yield and number of spike $/ \mathrm{m}^{2}, 1000$-grains weight and harvest index was highly positive significant $\left(0.953^{* *}, 0.895^{* *}\right.$ and $0.826 * *$, respectively) under this conditions.
\end{abstract}

Keywords: Wheat, Triticum aestivum L., Magnesium sulphate, Copper sulphate, Foliar application, Yield, Quality, sandy soil.

In Egypt, wheat (Triticum aestivum L.) is the most important cereal crop. The cultivated area of wheat reached to about 1.2 million hectare which produced about 7.9 million tons (FAO, 2008). It is clear that there is a great shortage in the production of wheat in Egypt. However, this production do not meet 
consumption partly due to over growing population and hence, consumption. The intensive competition between wheat and winter clover and sugar beet during the winter season limits the possibility of more extension in wheatcultivated area to more than 2.4 million fed in the old land. In addition, water resources and cultivated areas are limited. This reflects the dimension of the problem that shows the need of increasing vertical expansion in new desert area.

Cropping intensity in Egypt accompanied with shortage in fertilization led to a serious depletion of both macro and micronutrients from soil, especially in sandy soil. Magnesium has major physiological and molecular roles in plants, such as being a component of the chlorophyll molecule, a cofactor for many enzymatic processes associated with phosphorylation, dephosphorylation, and the hydrolysis of various compounds, and as a structural stabilizer for various nucleotides. Studies indicate that 15 to $30 \%$ of the total magnesium in plants is associated with the chlorophyll molecule (Marschner, 1995). Hanna \& Abdel Mottaleb (1998) concluded that the Magnesium fertilization as foliar application tended to increase grain, straw yield and 1000-kernel weight, number of grains/spike and grain content of $\mathrm{Mg}^{2+} \mathrm{P}, \mathrm{K}$, and crude protein. El-Amry et al. (2001) reported that maximum grain yield and protein and total carbohydrate contents of wheat grains were obtained with application of $5-10 \mathrm{~kg} \mathrm{MgSO}_{4} /$ fed. In Egypt, $\mathrm{Mg}$ decrease year after year in cultivated soils (Nofal \& El-Fouly, 2003) may be because, after constructing the High Dame, large quantities of Nile mud, which was renewing soil fertility annually, were decanted in Lake Nasser.

Copper is an essential micronutrient required for the functioning of more than 30 enzymes, all of which are either redox catalysts (e.g., cytochrome oxidase and nitrate reductase) or dioxygen carriers (e.g., haemocyanin). Ziaeian \& Malakouti (2001) reported that copper, as well as other micronutrient application, led to significantly increase in their concentration and uptake in grain and flag leaf of wheat. Such nutrient application increased significantly grain protein content. Shaaban (2002) showed that foliar fertilizer feeding containing $5.2 \% \mathrm{Mn}, 0.65 \% \mathrm{Zn}$ and $0.65 \% \mathrm{Cu}$ increased the concentration of $\mathrm{Mg}, \mathrm{Ca}, \mathrm{Fe}, \mathrm{Mn}, \mathrm{Zn}$ and $\mathrm{Cu}$ in the leaves of wheat. Zeidan \& Nofal (2003) showed that application of copper alone or adding $1 \%$ urea caused significant increases in grain protein content, yield and quality of wheat. Karamanos et al. (2004) reported that maximum grain yield of wheat was obtained by foliar application of $\mathrm{Cu}$. Korzeniowska (2008) found that wheat plants after $\mathrm{Cu}$ application showed higher $\mathrm{N}$ concentration than control plants. Moreover, high correlation between $\mathrm{Cu}$ and $\mathrm{N}$ concentration in wheat shoots were obtained.

The aim of this study was to evaluate the effect of magnesium sulphate and copper sulphate levels sprayed as foliar applications on growth, yield and quality of grain wheat under sandy soil condition.

Egypt. J. Agron. 33, No. 1 (2011) 


\section{Material and Methods}

Two field experiments were carried out at Ismailia exp. Sta., Agric. Res. Center, Egypt in 2007/2008 and 2008/2009 seasons to study the effect of two levels of copper sulphate and magnesium sulphate on growth, yield and quality of wheat (Triticum aestivum L. cv. Sakha 94). A representative soil sample from the experimental sites (0-30 $\mathrm{cm}$ depth) was taken after soil preparation and before fertilization. Physical and chemical characteristics of soil $(0-30 \mathrm{~cm}$ depth) are shown in Table 1 .

TABLE 1. Physical and chemical characteristics of soil $(0-30 \mathrm{~cm}$ depth) for both 2007/2008 and 2008/2009 seasons.

\begin{tabular}{|l|c|c|}
\hline Characteristics & $\mathbf{2 0 0 7 / 2 0 0 8}$ & $\mathbf{2 0 0 8 / 2 0 0 9}$ \\
\hline Sand (\%) & 88.4 & 90.0 \\
$\mathrm{Silt} \mathrm{( \% )}$ & 4.0 & 3.2 \\
Clay (\%) & 7.6 & 6.8 \\
Texture & Sand & Sand \\
Electric conductivity (dS/m) & 0.20 & 0.35 \\
$\mathrm{pH}$ & 8.95 & 9.15 \\
$\mathrm{CaCO}(\%)$ & 1.20 & 1.84 \\
Organic matter (\%) & 0.544 & 0.09 \\
$\mathrm{Macronutrients} \mathrm{(mg} \mathrm{/100} \mathrm{g} \mathrm{soil)}$ & & \\
$\mathrm{P}$ & 0.36 & 0.62 \\
$\mathrm{~K}$ & 7.60 & 4.24 \\
$\mathrm{Na}$ & 18.03 & 41.4 \\
$\mathrm{Ca}$ & 240 & 308 \\
$\mathrm{Mg}$ & 9.0 & 3.64 \\
$\mathrm{Micronutrients} \mathrm{(} \mathrm{ppm} \mathrm{)}$ & & \\
$\mathrm{Fe}$ & 3.70 & 3.83 \\
$\mathrm{Mn}$ & 2.80 & 1.13 \\
$\mathrm{Zn}$ & 0.22 & 0.15 \\
$\mathrm{Cu}$ & 0.10 & 0.25 \\
\hline
\end{tabular}

The experimental design was randomize complete block (RCBD) with six replicates.

In both seasons super phosphate $\left(15.5 \% \mathrm{P}_{2} \mathrm{O}_{5}\right)$ and potassium sulphate $(50 \%$ $\mathrm{K}_{2} \mathrm{O}$ ) fertilizers were added during preparation of the experimental land at the

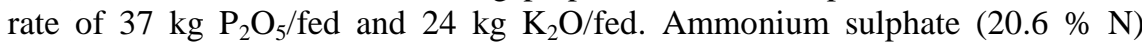
fertilizer at a rate of $106 \mathrm{~kg} \mathrm{~N} / \mathrm{fed}$ was applied as soil application in three equal splits at seeding, 30 and 50 day after sowing in both seasons. Magnesium in form of magnesium sulphate $(9 \% \mathrm{Mg})$ and copper in form of copper sulphate $(25 \%$ $\mathrm{Cu}$ ) with mixture of $\mathrm{Fe}, \mathrm{Mn}$ and $\mathrm{Zn}$ micronutrients in form of EDTA $13 \% \mathrm{Fe}$, EDTA $13.5 \% \mathrm{Mn}$ and EDTA $13.5 \% \mathrm{Zn}$ at a rate of $0.5 \mathrm{~g} / \mathrm{l}$ from each nutrient were sprayed of in 350 and 400-liter water/fed twice at 45 and 60 days after sowing in both seasons. 
Grains $(60 \mathrm{~kg} / \mathrm{fed})$ of wheat (Triticum aestivum L. cv. Sakha 94) were drilled by hand in rows spaced $20 \mathrm{~cm}$. Plants were irrigated at 6 days interval using sprinkler system.

The tested nine foliar spray treatments were as follow:

1. Control (water spray)

2. Magnesium sulphate at a rate of $3.36 \mathrm{~kg} / \mathrm{fed}$.

3. Magnesium sulphate at a rate of $6.72 \mathrm{~kg} / \mathrm{fed}$.

4. Copper sulphate at a rate of $0.84 \mathrm{~kg} / \mathrm{fed}$.

5. Copper sulphate at a rate of $1.68 \mathrm{~kg} / \mathrm{fed}$.

6. Magnesium sulphate at a rate of $3.36+$ copper sulphate at a rate of $0.84 \mathrm{~kg} / \mathrm{fed}$.

7. Magnesium sulphate at a rate of $3.36+$ copper sulphate at a rate of $1.68 \mathrm{~kg} / \mathrm{fed}$.

8. Magnesium sulphate at a rate of $6.72+$ copper sulphate at a rate of $0.84 \mathrm{~kg} / \mathrm{fed}$.

9. Magnesium sulphate at a rate of $6.72+$ copper sulphate at a rate of $1.68 \mathrm{~kg} / \mathrm{fed}$.

\section{Recorded data}

Growth characteristics

At 75 days after sowing, plants of $25 \times 25 \mathrm{~cm}^{2} /$ plot were taken to determine flag leaf area/plant and dry weight of shoots/unit area. Flag leaf area/plant was calculated using the formula (Length $\mathrm{x}$ maximum width $\mathrm{x} 0.79$ ) according to Voldeng \& Simpson (1967) Also, Chlorophyll content (mg/g) was recorded as a mean of 30 random readings. At harvest, plant height, number of tillers $/ \mathrm{m}^{2}$ and straw yield were determined.

\section{Plant elements extraction}

Plant shoots at 75 days age and grains after harvesting were dried in a ventilated oven at $70{ }^{\circ} \mathrm{C}$ till constant weight. The samples were ground in stainless steel mill with $0.5 \mathrm{~mm}$ sieve and kept in plastic containers for chemical analysis to determine the following traits:

a. Total nitrogen percentage: was determined using Micro-Kjeldahl method as described by Peter \& Young (1980). Protein content was obtained by multiplying the nitrogen content by 5.8 according to the method described by A.O.A.C. (2000).

b. Carbohydrate percentage in grains was measured using the method described by Duis et al. (1956).

c. Macro and micronutrients were extracted as described by Chapman \& Pratt (1978), using atomic absorption spectrophotometer apparatus (Zeiss PMQ3). Phosphorus was measured in the digested solution using vanado-molybdate color reaction, according to the method described by Jackson (1973). Potassium, calcium and sodium were measured using the Flamephotometer, (Eppendorof, DR Lang). 


\section{Yield and its components}

At maturity, plants of two square meters /plot were harvested to determine grain and straw yields as well as some agronomic attributes.

Collected data were subjected to the proper statistical analysis according to Snedecor \& Cochoran (1967). Since the data in both seasons took similar trends and variances were homogeneous according to Bartlett's test, the combined analysis of both seasons' data was done. LSD test at $5 \%$ level was used for comparing the numerical averages according to Waller \& Duncan (1969). Correlation coefficients were calculated for yield and yield components using the average among the two seasons.

\section{Results and Discussion}

Effect of Magnesium sulphate and copper sulphate foliar application on wheat growth attributes

Data in Table 2 show that all magnesium sulphate and/or copper sulphate levels significantly affected wheat plant height, number of tillers $/ \mathrm{m}^{2}$, flag leaf area, chlorophyll and total dry weight $/ \mathrm{m}^{2}$ at 75 days after sowing. The increment ranged between 4.14-10.89\% in plant height, $0.49-21.68 \%$ in tillers/plant, 19 $31 \%$ in flag leaf area, $7-29 \%$ in chlorophyll content and $22-88 \%$ in total dry weight, over control treatment. The highest increment of the mentioned parameters was recorded with spraying wheat plants by $6.72 \mathrm{~kg} \mathrm{MgSO}_{4}+1.68 \mathrm{~kg}$ $\mathrm{CuSO}_{4} / \mathrm{fed}$.

TABLE 2. Effect of $\mathrm{MgSO}_{4}$ and $\mathrm{CuSO}_{4}$ on some growth characteristics of wheat (combined data of 2007/2008 and 2008/2009 seasons).

\begin{tabular}{|c|c|c|c|c|c|c|c|}
\hline \multicolumn{2}{|c|}{ Treatments } & \multirow{3}{*}{$\begin{array}{l}\text { Plant } \\
\text { height } \\
(\mathbf{c m})\end{array}$} & \multirow{3}{*}{$\begin{array}{c}\text { Tillers / } \\
\text { m}^{2} \\
(\mathbf{n o})\end{array}$} & \multirow{3}{*}{$\begin{array}{c}\text { Flag leaf } \\
\text { area } \\
\left(\mathrm{cm}^{2}\right)\end{array}$} & \multirow{3}{*}{$\begin{array}{c}\text { Shoots } \\
\text { dry } / \mathrm{m}^{2} \\
\text { (g) }\end{array}$} & \multirow{3}{*}{$\begin{array}{c}\text { Chlorophyll } \\
(\mathrm{mg} / \mathrm{g})\end{array}$} & \multirow{3}{*}{$\begin{array}{c}\text { Straw } \\
\text { yield } \\
\text { (ton/fed) }\end{array}$} \\
\hline $\mathrm{MgSO}_{4}$ & $\mathrm{CuSO}_{4}$ & & & & & & \\
\hline \multicolumn{2}{|c|}{ (kg/fed.*) } & & & & & & \\
\hline 0 & 0 & 84.5 & 690.3 & 19.23 & 463.4 & 2.22 & 2.63 \\
\hline 3.36 & 0 & 88.0 & 693.7 & 22.85 & 567.3 & 2.38 & 4.35 \\
\hline 6.72 & 0 & 89.3 & 734.0 & 24.00 & 604.6 & 2.52 & 4.59 \\
\hline 0 & 0.84 & 87.7 & 767.3 & 23.25 & 577.3 & 2.55 & 5.01 \\
\hline 0 & 1.68 & 89.5 & 826.7 & 24.23 & 632.0 & 2.60 & 4.45 \\
\hline 3.36 & 0.84 & 90.3 & 840.0 & 24.42 & 686.4 & 2.57 & 4.70 \\
\hline 3.36 & 1.68 & 90.8 & 778.3 & 24.53 & 766.8 & 2.70 & 4.80 \\
\hline 6.72 & 0.84 & 89.8 & 757.0 & 24.07 & 810.4 & 2.78 & 4.32 \\
\hline 6.72 & 1.68 & 94.8 & 826.7 & 25.13 & 871.8 & 2.85 & 4.78 \\
\hline \multicolumn{2}{|c|}{ LSD at 0.05} & 3.4 & 77.4 & 1.78 & 40.5 & 0.15 & 0.91 \\
\hline
\end{tabular}

Positive effect of magnesium and copper sulphate applied as foliar application on wheat growth can be attributed to the important function of copper in plant 
metabolism since copper participates in photosynthesis and chloroplast development (Amberger, 1974). Since magnesium is the central atom in the chlorophyll molecule it is essential for photosynthesis and plays a critical role in plant growth.

Marschner (1995) and El-Magid et al. (2000) reported that application of $\mathrm{Cu}$ at $0.1 \%$ with other micronutrients increased the number of shoots/ wheat plants. Kumar et al. (2009) found that production of wheat dry matter enhanced with increasing $\mathrm{Cu}$ levels and reached to the maximum at $1.5 \mathrm{MgSO}_{4} \mathrm{~kg} / \mathrm{fed}$.

\section{Yield and its components}

Foliar application with magnesium sulphate $\left(\mathrm{MgSO}_{4}\right)$ and/or copper sulphate $\left(\mathrm{CuSO}_{4}\right)$ had a significant effect on number of spikes $/ \mathrm{m}^{2}$, spike length, and number of grains/spike of wheat (Table 3). Spraying wheat plants with $3.36 \mathrm{~kg}$ $\mathrm{MgSO}_{4}+0.84 \mathrm{~kg} \mathrm{CuSO}_{4} /$ fed produced the greatest increase in spike length as compared with control and other treatments. Meanwhile, the highest number of grains/spike was obtained by application of $6.72 \mathrm{~kg} \mathrm{MgSO}_{4}+0.84 \mathrm{~kg} \mathrm{CuSO}_{4} /$ fed. The highest values for grains weight/spike and 1000-grain weight were determined by $6.72 \mathrm{~kg} \mathrm{MgSO} 4+0.84 \mathrm{~kg} \mathrm{CuSO}_{4}$ /fed. High level of copper sulphate $(1.68 \mathrm{~kg} / \mathrm{fed})$ produced the greatest grain yield and harvest index. The lowest grain yield, harvest index and yield components were resulted from the untreated plants.

TABLE 3. Yield and yield components of wheat plant as affected by copper sulphate $\left(\mathrm{CuSO}_{4}\right)$ and magnesium sulphate $\left(\mathrm{MgSO}_{4}\right)$ foliar applications (combined data of 2007/2008 and 2008/2009 seasons).

\begin{tabular}{|c|c|c|c|c|c|c|c|c|}
\hline \multicolumn{2}{|c|}{ Treatments } & \multirow{3}{*}{$\begin{array}{c}\text { Spikes } \\
\text { No. / m² } \\
\text { (no) }\end{array}$} & \multirow{3}{*}{$\begin{array}{c}\text { Spike } \\
\text { length } \\
(\mathrm{cm})\end{array}$} & \multirow{3}{*}{$\begin{array}{c}\text { Grains/ } \\
\text { spike } \\
\text { (no) }\end{array}$} & \multirow{3}{*}{$\begin{array}{c}\text { Grains/ } \\
\text { spike } \\
\text { (g) }\end{array}$} & \multirow{3}{*}{$\begin{array}{c}\text { 1000- } \\
\text { grains } \\
\text { weight } \\
\text { (g) }\end{array}$} & \multirow{3}{*}{$\begin{array}{l}\text { Grain } \\
\text { yield/ } \\
\text { fed } \\
(\text { ard })^{*}\end{array}$} & \multirow{3}{*}{$\begin{array}{c}\text { Harvest } \\
\text { index }\end{array}$} \\
\hline $\mathrm{MgSO}_{4}$ & $\mathrm{CuSO}_{4}$ & & & & & & & \\
\hline \multicolumn{2}{|c|}{$(\mathrm{kg} / \mathrm{fed})$} & & & & & & & \\
\hline 0 & 0 & 581.3 & 7.72 & 22.3 & 0.77 & 30.6 & 7.9 & 0.29 \\
\hline 3.36 & 0 & 621.3 & 8.77 & 31.5 & 1.15 & 33.0 & 10.2 & 0.29 \\
\hline 6.72 & 0 & 680.5 & 9.17 & 33.5 & 1.27 & 36.2 & 10.8 & 0.28 \\
\hline 0 & 0.84 & 733.3 & 9.03 & 29.8 & 1.18 & 39.1 & 13.1 & 0.34 \\
\hline 0 & 1.68 & 773.3 & 8.80 & 36.5 & 1.25 & 40.4 & 14.5 & 0.37 \\
\hline 3.36 & 0.84 & 768.0 & 9.13 & 35.7 & 1.40 & 37.0 & 13.2 & 0.32 \\
\hline 3.36 & 1.68 & 678.0 & 9.13 & 34.8 & 1.13 & 37.6 & 12.4 & 0.30 \\
\hline 6.72 & 0.84 & 691.2 & 9.08 & 36.5 & 1.45 & 41.1 & 12.2 & 0.32 \\
\hline 6.72 & 1.68 & 757.3 & 8.90 & 32.7 & 1.25 & 40.9 & 13.8 & 0.34 \\
\hline \multicolumn{2}{|c|}{ LSD at 0.05} & 48.9 & 0.75 & 3.8 & 0.20 & 3.8 & 1.9 & 0.04 \\
\hline
\end{tabular}

Egypt. J. Agron. 33, No. 1 (2011) 
The increase in grain yield /fed due to copper sulphate and magnesium sulphate treatments can be attributed to the increase in yield components of wheat. The increase in number of grains due to copper sulphate and magnesium sulphate application may be attributed to copper and magnesium efficiency in addition to more fertile-spikelets which ought to be not formed in case of copper and magnesium deficiency.

Such effects of foliar application with $\mathrm{MgSO}_{4}$ and/or $\mathrm{CuSO}_{4}$ might be due to their critical role in crop growth, implicated in photosynthesis processes, respiration and other biochemical and physiological activates. These results are similar to those of Zeidan \& Nofal (2003), El-Maghraby (2004) and Kumar et al. (2009). Whereas, El-Amry et al. (2001) and Hussein (2005) showed that grain yield of wheat plants was affected positively by application of magnesium.

Macronutrient and Micronutrient contents in wheat shoots at 75 days age

Results in Table 4 show that macronutrient concentration in wheat shoots were differed significantly with different treatments. The highest percent of $\mathrm{N}, \mathrm{P}$, $\mathrm{K}, \mathrm{Mg}$ and $\mathrm{Ca}$ in wheat shoots were recorded as a result of adding $6.72 \mathrm{~kg}$ $\mathrm{MgSO}_{4}+1.68 \mathrm{~kg} \mathrm{CuSO}_{4} / \mathrm{fed}$ as foliar application. From the above-mentioned results, it could be concluded that $\mathrm{MgSO}_{4}$ and $\mathrm{CuSO}_{4}$ application to plants of wheat at 75 days after sowing increased $\mathrm{N}, \mathrm{P}, \mathrm{K}, \mathrm{Mg}$ and $\mathrm{Ca}$ contents in wheat shoots. The highest $\mathrm{N}, \mathrm{P}, \mathrm{K}, \mathrm{Mg}$ and $\mathrm{Ca}$ contents in wheat shoots were obtained by spraying wheat plants with $6.72 \mathrm{~kg} \mathrm{MgSO}_{4}+1.68 \mathrm{~kg} \mathrm{CuSO}_{4} / \mathrm{fed}$ at 75 days after sowing. The increase in macronutrient contents may be due to $\mathrm{Mg}$ and $\mathrm{CuSO}_{4}$ plays a major role in photosynthesis. The formation of important synthesates like ATP, ADP, chlorophyll and other pigments, sugar, DNA, RNA,...etc,. Proper magnesium and copper doses increased nutrient contents through proper uptake and assimilation. These results are in agreement with those of El-Magid et al. (2000), Moussa (2000), Shaaban (2002), Abdel-Maguid et al. (2004), and Korzeniowska (2008) whom found that application of $\mathrm{Cu}$ in wheat plants led to the increase of macronutrient contents in wheat shoots. While, Brohi et al. (2000) showed that foliar application of $\mathrm{Mg}$ on rice and wheat plants increased the concentrations of macronutrients in plant shoots.

Micronutrient concentrations in wheat shoots were significantly differed according to applied magnesium and copper sulphate rates (Table 4). It is obvious that the highest $\mathrm{Fe}, \mathrm{Mn}$ and $\mathrm{Zn}$ concentrations were found in wheat plants sprayed with $6.72 \mathrm{~kg} \mathrm{MgSO}_{4}+1.68 \mathrm{~kg} \mathrm{CuSO} /$ fed. Meanwhile, the highest $\mathrm{Cu}$ content in wheat shoots was obtained from $3.36 \mathrm{~kg} \mathrm{MgSO} 4+1.68 \mathrm{~kg}$ $\mathrm{CuSO}_{4} / \mathrm{fed}$ application (19.3 ppm). From the above mentioned results, it could be concluded that $\mathrm{MgSO}_{4}$ and $\mathrm{CuSO}_{4}$ application to wheat plants increased the contents of $\mathrm{Fe}, \mathrm{Zn}, \mathrm{Mn}$ and $\mathrm{Cu}$ in wheat shoots at 75 days after sowing. The obtained results support those of Ibrahim \& Shalaby (1994), El-Badry (1995), Moussa (2000), Shaaban (2002), Abdel-Maguid et al. (2004) and El-Maghraby (2004) with $\mathrm{Cu}$ application to wheat plants, while Brohi et al. (2000) found that uptake of all nutrients in wheat straw was higher with $\mathrm{Mg}$ application. 
TABLE 4. Effect of magnesium sulphate and copper sulphate on macronutrient and micronutrient contents of wheat shoots at 75 days after sowing (combined of 2007/2008 and 2008/2009 seasons).

\begin{tabular}{|c|c|c|c|c|c|c|c|c|c|c|}
\hline \multicolumn{2}{|c|}{ Treatments } & \multirow{2}{*}{\multicolumn{5}{|c|}{ Macronutrient (\%) }} & \multirow{2}{*}{\multicolumn{4}{|c|}{ Micronutrient (ppm) }} \\
\hline $\mathrm{MgSO}_{4}$ & $\mathrm{CuSO}_{4}$ & & & & & & & & & \\
\hline \multicolumn{2}{|c|}{$\mathrm{kg} / \mathrm{fed}$} & $(\mathrm{N})$ & (P) & (K) & (Mg) & (Ca) & $(\mathrm{Fe})$ & (Zn) & (Mn) & $(\mathbf{C u})$ \\
\hline 0 & 0 & 1.73 & 0.21 & 2.70 & 0.14 & 0.32 & 114.0 & 31.2 & 18.0 & 5.2 \\
\hline 3.36 & 0 & 2.49 & 0.24 & 3.32 & 0.15 & 0.35 & 139.6 & 38.4 & 21.2 & 6.0 \\
\hline 6.72 & 0 & 2.70 & 0.28 & 3.94 & 0.17 & 0.44 & 153.0 & 40.4 & 25.3 & 6.3 \\
\hline 0 & 0.84 & 2.55 & 0.26 & 3.67 & 0.14 & 0.41 & 135.4 & 38.6 & 23.5 & 10.6 \\
\hline 0 & 1.68 & 2.71 & 0.26 & 3.95 & 0.14 & 0.45 & 155.7 & 40.8 & 24.8 & 17.1 \\
\hline 3.36 & 0.84 & 2.40 & 0.29 & 3.26 & 0.16 & 0.50 & 156.9 & 41.9 & 25.2 & 12.1 \\
\hline 3.36 & 1.68 & 2.68 & 0.29 & 3.57 & 0.16 & 0.50 & 163.8 & 48.2 & 25.7 & 19.3 \\
\hline 6.72 & 0.84 & 2.85 & 0.29 & 3.47 & 0.18 & 0.51 & 164.5 & 48.0 & 26.3 & 12.5 \\
\hline 6.72 & 1.68 & 3.06 & 0.30 & 3.84 & 0.18 & 0.51 & 176.5 & 50.0 & 27.0 & 18.9 \\
\hline \multicolumn{2}{|c|}{ LSD at 0.05} & 0.07 & 0.01 & 0.35 & 0.01 & 0.06 & 7.6 & 6.7 & 2.4 & 1.5 \\
\hline
\end{tabular}

Grain quality

Quality parameters of wheat grains (protein and carbohydrates) showed significant response to magnesium sulphate and/or copper sulphate foliar application treatments (Table 5). Spraying wheat plants with the mixture of magnesium sulphate and copper sulphate at the higher rate $\left(6.72 \mathrm{~kg} \mathrm{MgSO}_{4}+\right.$ $1.68 \mathrm{~kg} \mathrm{CuSO} / / \mathrm{fed})$ resulted in achieving the highest value of grain protein content $(14.98 \%)$ compared with other treatments. Magnesium has functions in protein synthesis that can affect the size, structure, and function of chloroplasts (Marschner, 1995). But, magnesium and copper sufficient levels increased protein content indirectly through its role in nutrients balance in plant tissues. The present results are in the same direction with those reported by Ziaeian \& Malakouti (2001) and Zeidan \& Nofal (2003) with copper application on wheat plants and El-Amry et al. (2001) and LiXin et al. (2003) with magnesium application on wheat plants.

Concerning results in Table 5, they indicate that $0.84 \mathrm{~kg} \mathrm{CuSO}_{4} /$ fed gave the highest carbohydrate in grains $(69.33 \%)$ as compared with untreated plants and other treatments. This indicates that no increase in copper sulphate and magnesium sulphate level more than $0.84 \mathrm{~kg} \mathrm{CuSO}_{4}$ and $3.36 \mathrm{~kg} \mathrm{MgSO}_{4} / \mathrm{fed}$ is needed for obtaining high carbohydrate content of grains. Even the contribution Egypt. J. Agron. 33, No. 1 (2011) 
of these minerals in photosynthesis and enzymes controlling carbohydrate formation, the minimum requirements of copper and magnesium were enough to accumulate suitable carbohydrate contents. Migahid \& Sadek (1994) found that carbohydrate content in wheat plants was significantly increased by copper application. Also, El-Amry et al. (2001) reported that maximum grain total carbohydrate of wheat was obtained by application of $\mathrm{MgSO}_{4}$ with 5 or $10 \mathrm{~kg} / \mathrm{fed}$.

\section{Grain chemical constituents}

Grains contents of $\mathrm{N}, \mathrm{Mg}, \mathrm{Cu}$ and $\mathrm{Zn}$ showed significant response to magnesium sulphate and copper sulphate foliar application treatments (Table 5). Spraying wheat plants with $6.72 \mathrm{~kg} \mathrm{MgSO}_{4}+1.68 \mathrm{~kg} \mathrm{CuSO}_{4} /$ fed produced the highest increase in grains nitrogen content.

TABLE 5. Wheat grain contents of protein, carbohydrate, $\mathrm{N}, \mathrm{Mg}, \mathrm{Cu}$ and $\mathrm{Zn}$ as affected by magnesium sulphate $\left(\mathrm{MgSO}_{4}\right)$ and copper sulphate $\left(\mathrm{CuSO}_{4}\right)$ foliar applications (combined data of 2007/2008 and 2008/2009 seasons).

\begin{tabular}{|c|c|c|c|c|c|c|c|}
\hline \multicolumn{2}{|c|}{ Treatments } & \multirow{3}{*}{$\begin{array}{c}\text { Protein } \\
(\%)\end{array}$} & \multirow{3}{*}{$\begin{array}{c}\text { Carbohydrate } \\
(\%)\end{array}$} & \multirow{3}{*}{$\begin{array}{l}N \\
(\%)\end{array}$} & \multirow{3}{*}{$\begin{array}{l}\text { Mg } \\
(\%)\end{array}$} & \multirow{3}{*}{$\underset{(\mathbf{p p m})}{\mathbf{C u}}$} & \multirow{3}{*}{$\begin{array}{c}\mathbf{Z n} \\
(\mathbf{p p m})\end{array}$} \\
\hline $\mathrm{CuSO}_{4}$ & $\mathrm{CuSO}_{4}$ & & & & & & \\
\hline \multicolumn{2}{|c|}{ kg/fed } & & & & & & \\
\hline 0 & 0 & 6.37 & 61.67 & 1.12 & 0.26 & 3.30 & 34.80 \\
\hline 3.36 & 0 & 11.90 & 63.67 & 2.07 & 0.27 & 4.40 & 39.70 \\
\hline 6.72 & 0 & 12.82 & 65.33 & 2.22 & 0.29 & 4.50 & 42.40 \\
\hline 0 & 0.84 & 12.03 & 69.33 & 2.08 & 0.29 & 5.30 & 45.80 \\
\hline 0 & 1.68 & 12.78 & 68.17 & 2.23 & 0.29 & 7.20 & 48.70 \\
\hline 3.36 & 0.84 & 13.52 & 67.83 & 2.33 & 0.32 & 5.40 & 46.90 \\
\hline 3.36 & 1.68 & 14.07 & 67.33 & 2.42 & 0.33 & 7.50 & 48.30 \\
\hline 6.72 & 0.84 & 14.98 & 67.17 & 2.58 & 0.35 & 5.60 & 50.90 \\
\hline 6.72 & 1.68 & 15.45 & 67.33 & 2.65 & 0.35 & 7.90 & 54.40 \\
\hline \multicolumn{2}{|c|}{ LSD at 0.05} & 0.43 & 0.75 & 0.07 & 0.01 & 0.97 & 3.60 \\
\hline
\end{tabular}

Sufficient levels of magnesium and copper increased nitrogen content indirectly through their role in nutrients uptake and balance in plant tissues. The present results are in the same direction with those reported by Ziaeian \& Malakouti (2001) and Zeidan \& Nofal (2003) with copper application and ElAmry et al. (2001) and Lixin et al. (2003).

Application of magnesium sulphate, copper sulphate or both of them increased grain magnesium content (\%) as compared with control plants. The 
differences between $6.72 \mathrm{~kg} \mathrm{MgSO}_{4}+0.84 \mathrm{~kg} \mathrm{CuSO}_{4}$ and $6.72 \mathrm{~kg} \mathrm{MgSO}_{4}+1.68 \mathrm{~kg}$ $\mathrm{CuSO}_{4} / \mathrm{fed}$ treatments did not reach to the level of significance. Spraying wheat plants with $6.72 \mathrm{~kg} \mathrm{MgSO}_{4}+0.84 \mathrm{~kg} \mathrm{CuSO}_{4}$ and $6.72 \mathrm{~kg} \mathrm{MgSO}_{4}+1.68 \mathrm{~kg}$ $\mathrm{CuSO}_{4} /$ fed produced the highest increment in magnesium content $(0.35$ and $0.35 \%)$, while, the lowest values $(0.26 \%)$ were recorded with control plants.

From the above mentioned results, it could be concluded that magnesium sulphate and copper sulphate application produced wheat grains with high contents of $\mathrm{Mg}$ in the second season and combined analysis of the two seasons. Similar results were also obtained by Hanna \& Abdel Mottaleb (1998) who reported that application of magnesium as a soil application increased the grain content of Mg. Brohi et al. (2000) found that application of magnesium increased rice $\mathrm{Mg}$ content in grains.

Data in Table 5 showed that foliar spray of magnesium sulphate and copper sulphate significantly increased $\mathrm{Cu}$ content of wheat grains compared to control treatment. Application of $3.6 \mathrm{~kg} \mathrm{MgSO}_{4}+1.68 \mathrm{~kg} \mathrm{CuSO}_{4} / \mathrm{fed}$ and $6.72 \mathrm{~kg} \mathrm{MgSO}+$ $1.68 \mathrm{~kg} \mathrm{CuSO}_{4} /$ fed gave the highest grain $\mathrm{Cu}$ content $(7.50$ and $7.90 \mathrm{ppm}$, respectively). Similar positive effects of wheat copper content of grains were obtained by Ibrahim \& Shalaby (1994) and El-Badry (1995). In contrast, ElMagid et al. (2000) reported that $\mathrm{Cu}$ content was declined in wheat grains as the plants received copper.

\section{Straw chemical constituents}

Chemical composition of straw i.e, $\mathrm{Mg}, \mathrm{Cu}$ and $\mathrm{Zn}$ concentrations showed significant response to magnesium sulphate and copper sulphate foliar application treatments (Table 6). Wheat plants sprayed with magnesium sulphate or copper sulphate or magnesium sulphate + copper sulphate significantly increased magnesium concentration of wheat straw as compared with unsprayed plants. Spraying wheat plants with $6.72 \mathrm{~kg} \mathrm{MgSO}_{4}+0.84 \mathrm{~kg} \mathrm{CuSO}_{4} / \mathrm{fed}$ and $6.72 \mathrm{~kg}$ $\mathrm{MgSO}_{4}+1.68 \mathrm{~kg} \mathrm{CuSO}_{4} /$ fed produced the highest magnesium concentration of wheat straw $(0.28 \%)$. From the above-mentioned results, it could be concluded that application of $6.72 \mathrm{~kg} \mathrm{MgSO}_{4}+1.68 \mathrm{~kg} \mathrm{CuSO} / \mathrm{fed}$ gave the highest magnesium, copper and $\mathrm{Zn}$ content $(0.28 \%, 3.80 \mathrm{ppm}$ and $46.20 \mathrm{ppm}$, respectively) in wheat straw as compared with unsprayed plants. Spraying wheat plants with each of $1.68 \mathrm{~kg} \mathrm{CuSO}_{4} / \mathrm{fed}, 3.36 \mathrm{~kg} \mathrm{MgSO}_{4}+1.68 \mathrm{~kg} \mathrm{CuSO}_{4} / \mathrm{fed}$ and $6.72 \mathrm{~kg} \mathrm{MgSO}_{4}+1.68 \mathrm{~kg} \mathrm{CuSO}_{4} /$ fed produced the highest copper concentration $(3.80 \mathrm{ppm})$ in wheat straw.

From the above-mentioned results, it could be concluded that $\mathrm{MgSO}_{4}$ and/or $\mathrm{CuSO}_{4}$ applications increased $\mathrm{Mg}, \mathrm{Cu}$ and $\mathrm{Zn}$ concentration in wheat straw. The positive effect of magnesium sulphate and/or copper sulphate foliar application on $\mathrm{Mg}, \mathrm{Cu}$ and $\mathrm{Zn}$ concentration in wheat straw may be due to copper and magnesium sufficient levels in the plant tissues (Brohi et al., 2000). 
TABLE 6. Effect of copper sulphate $\left(\mathrm{CuSO}_{4}\right)$ and magnesium sulphate $\left(\mathrm{MgSO}_{4}\right)$ on macro-micronutrient contents of wheat straw at harvesting (combined of 2007/2008 and 2008/2009 seasons).

\begin{tabular}{|c|c|c|c|c|}
\hline \multicolumn{2}{|c|}{ Treatments } & \multirow{3}{*}{$\begin{array}{c}\mathrm{Mg} \\
(\%)\end{array}$} & \multirow{3}{*}{$\underset{(\mathbf{p p m})}{\mathbf{C u}}$} & \multirow{3}{*}{$\begin{array}{c}\mathbf{Z n} \\
(\mathbf{p p m})\end{array}$} \\
\hline $\mathrm{MgSO}_{4}$ & $\mathrm{CuSO}_{4}$ & & & \\
\hline \multicolumn{2}{|c|}{ kg/fed } & & & \\
\hline 0 & 0 & 0.19 & 1.60 & 24.90 \\
\hline 3.36 & 0 & 0.23 & 2.30 & 29.60 \\
\hline 6.72 & 0 & 0.26 & 2.40 & 32.20 \\
\hline 0 & 0.84 & 0.20 & 2.80 & 33.30 \\
\hline 0 & 1.68 & 0.20 & 3.80 & 38.10 \\
\hline 3.36 & 0.84 & 0.26 & 2.90 & 37.50 \\
\hline 3.36 & 1.68 & 0.27 & 3.80 & 41.30 \\
\hline 6.72 & 0.84 & 0.28 & 2.90 & 43.70 \\
\hline 6.72 & 1.68 & 0.28 & 3.80 & 46.20 \\
\hline \multicolumn{2}{|c|}{ LSD at 0.05} & 0.01 & 0.30 & 4.80 \\
\hline
\end{tabular}

Data in Table 7 indicate that correlation coefficients were significant between grain yield/fed and plant height, number of spike $/ \mathrm{m}^{2}$, spike length, number of grains/spike, grains weight /spike, 1000-grains weight, harvest index, straw yield/fed and grain protein percentage. All of the calculated correlation coefficients were positive. Correlation coefficients were significant and/or highly significant between all studied characters except the correlation coefficients between plant height and each of number of spike $/ \mathrm{m}^{2}$, spike length, number of grains/spike, grains weight/spike and harvest index and also between harvest index and spike length, number of grains/spike, grains weight/spike, straw yield/fed and grain protein percentage.

Correlation coefficients were not significant between spike length and number of spike $/ \mathrm{m}^{2}$. In this concern, Rady et al. (1981) and Salem et al. (1990) found that the phenotypic correlation coefficients were highly significant and positive between wheat grain yield and each of spike grains weight, 1000-grains weight, number of grains/spike, number of spikelets/spike and straw yield/feddan. 
TABLE 7. Correlation coefficients between grain yield and yield components.

\begin{tabular}{|c|c|c|c|c|c|c|c|c|c|}
\hline Characters & $\begin{array}{c}\text { Grain } \\
\text { yield / } \\
\text { fed }\end{array}$ & $\begin{array}{c}\text { Plant } \\
\text { heigh } \\
\text { t } \\
(\mathrm{cm})\end{array}$ & $\begin{array}{c}\text { Spike } \\
/ \mathbf{m}^{2} \\
\text { (no) }\end{array}$ & $\begin{array}{c}\text { Spike } \\
\text { length } \\
(\mathrm{cm})\end{array}$ & $\begin{array}{c}\text { Grain } \\
\text { / spike } \\
\text { (no) }\end{array}$ & $\begin{array}{c}\text { Grain } \\
\text { / spike } \\
\text { (g) }\end{array}$ & $\begin{array}{l}\text { 1000- } \\
\text { grain } \\
\text { S (g) }\end{array}$ & $\begin{array}{c}\text { Harves } \\
\text { t index } \\
(\%)\end{array}$ & $\begin{array}{c}\text { Stra } \\
\text { w } \\
\text { yield } \\
\text { / fed }\end{array}$ \\
\hline Grain yield/fed & 1.00 & & & & & & & & \\
\hline Plant height & $0.72 *$ & 1.00 & & & & & & & \\
\hline Spikes $/ \mathrm{m}^{2}$ & $0.95 *$ & 0.66 & 1.00 & & & & & & \\
\hline Spike length & $0.68 *$ & 0.63 & 0.62 & 1.00 & & & & & \\
\hline Grains/spike(no & $0.75^{*}$ & 0.66 & $0.68 *$ & $0.85^{*}$ & 1.00 & & & & \\
\hline Grains /spike & $0.69 *$ & 0.62 & $0.70 *$ & $0.85 *$ & $0.89 * *$ & 1.00 & & & \\
\hline 1000-grains (g) & $\begin{array}{l}0.90 * \\
*\end{array}$ & $0.72 *$ & $\begin{array}{l}0.82 * \\
*\end{array}$ & $0.67 *$ & $0.73 *$ & $0.74 *$ & 1.00 & & \\
\hline Harvest index & $\begin{array}{l}0.83 * \\
*\end{array}$ & 0.37 & $0.80 *$ & 0.19 & 0.38 & 0.35 & $0.74 *$ & 1.00 & \\
\hline Straw yield/fed & $0.79 *$ & $0.68 *$ & $0.72 *$ & $\begin{array}{l}0.93 * \\
*\end{array}$ & $0.73 *$ & $0.73 *$ & $0.70 *$ & 0.37 & 1.00 \\
\hline
\end{tabular}

\section{Conclusions}

From the present work it could be concluded that magnesium sulphate and copper sulphate fertilization is very important for the growth of wheat plants under sandy condition. $6.72 \mathrm{~kg} \mathrm{MgSO}_{4}+1.68 \mathrm{~kg} \mathrm{CuSO} /$ fed could be used as foliar fertilizer rates to obtain high wheat growth parameters (e.g. leaf flag area, chlorophyll and dry matter accumulation).

\section{References}

A.O.A.C. (2000) "Official Methods of Analysis of the Association of Official Analytical Chemists", International. $17^{\text {th }}$ edition. Association of Official Analytical Chemists International, Maryland, U SA, 350 pp.

Abdel-Maguid, A. A., El-Fouly, M. M. and El-Nour, E. A. A. (2004) Copper as a yield limiting nutrient for wheat. Bulletin Fac. Agric., Cairo Univ. 55(3), 385-400.

Amberger, A. (1974) Micronutrients, dynamics in the soil and function in plant metabolism. IV. Copper. Proc. Egypt Botany Society. Workshop 1, Cairo, pp 113-120.

Brohi, A.R., Karaman, M.R., Topbas, M.T., Aktas, A. and Savasli, E. (2000) Effect of potassium and magnesium sulphate fertilization on yield and nutrient content of rice crop grown on artificial siltation soil. Turk J. Agric. 24, 429-435.

Chapman, H.D. and Pratt, P.F. (1978) "Methods of Analysis for Soils, Plants and Water", University California, Department Agriculture Science USA, 320 p.

Duis, M., Gilles, Hamilton, J.K., Robers, P.A. and Smith, F. (1956) Colorimetric method for determination of sugar and related substances. Analytical Chemistry, $\mathbf{2 8}$ (3), 350-356.

Egypt. J. Agron. 33, No. 1 (2011) 
El-Amry, H.G., Mahdy, A.M. and Salam, S.M.A. (2001) Efficacy of combination between $\mathrm{Mg}$ and $\mathrm{N}$ fertilization on the chemical composition and technological properties of wheat grains. Egyptian J. Agric. Res. 79(3), 1085-1098.

El-Badry, O.Z. (1995) Effect of nitrogen and copper fertilization on yield and quality of wheat. Annals Agric. Sci, Moshtohor, 33 (3), 1017-1024.

El-Magid, A.A.A., Knany, R.E. and El-Fotoh, H.G.A. (2000) Effect of foliar application of some micronutrients on wheat yield and quality. Annals Agric. Sci. Cairo, 1(Special), 301-313.

El-Maghraby, T.A. (2004) Effect of wheat grain soaking in some micronutrient solutions on crop production under rainfall condition. Egyptian J. Soil Sci. 44 (3), 429-440.

FAO (2008) Food and Agriculture Organization of the United Nation, Economic and Social Department.

Hanna, N.S. and Abdel Mottaleb, F.A. (1998) Response to Magnesium sulphate fertilization under different nitrogen fertilizer levels in wheat (Triticum aesitivum L). Egypt. J. Appl. Sci. 13(5), 168-177.

Hussein, S.M.A. (2005) Effect of supplemental irrigations, seeding rates and foliar application of potassium and macro-micro elements on wheat productivity under rainfed conditions. Bulletin of Faculty of Agriculture, Cairo Univ. 6(3), 431-453.

Ibrahim, M. E. and Shalaby, M . H. (1994) Effect of some micronutrients and methods of their application on growth, yield and mineral composition of wheat. Annals Agric. Sci., Moshtohor, 32 (3), 1371-1388.

Jackson, M.I. (1973) “Soil Chemical Analysis”. Prentice Hall of India, New Delhi.

Karamanos, R. E., Pomarenski, Q., Goh, T.B. and Flore, N.A. (2004) The effect of foliar copper application on grain yield and quality of wheat. Canadian J. Plant Sci. $84(1), 47-56$

Korzeniowska, J. (2008) Winter wheat response to copper application under different cultivation technologies and nitrogen fertilization. Ecological Chemistry and Engineering, 15 (1, 2), 81-88.

Kumar, R., Mehrotra, N.K., Nautiyal, B.D., Kumar, P. and Singh, P.K. (2009) Effect of copper on growth, yield and concentration of $\mathrm{Fe}, \mathrm{Mn}, \mathrm{Zn}$ and $\mathrm{Cu}$ in wheat plants (Triticum aestivum L.). J. of Environmental Biology, 30 (4), 485-488.

LiXin, X., HuiJie, Z., ZhanLing, G. and YanFeng, X. (2003) Effect of molybdenum, zinc and magnesium fertilizer sprayed in grain-filling stage on wheat quality. J. Henan Agric. Univ. 37 (3), 217- 223.

Marschner, H. (1995) "Mineral Nutrition of Higher Plants". $2^{\text {nd }}$ ed. New York, USA: Academic Press, Harcourt Brace Jovanovich, Publisher. 674 p.

Migahid, M.M. and Sadek, L.A. (1994) Effect of presoaking with trace elements on salt tolerance of three cultivars of wheat. Alexandria J. Agric. Res. 39 (3), 501-515.

Egypt. J. Agron. 33, No. 1 (2011) 
Moussa, B. I. M. (2000) Response of wheat plants grown in sandy soils to K and some micronutrients fertilization. Egyptian J. Soil Sci. 40 (4), 481-493.

Nofal, O. A. and El-fouly, M. M. (2003) Magnesium in soils and crops in Egypt. AFA $9^{\text {th }}$ International Annual Conference, 28-30 ${ }^{\text {th }}$ January, 2003, Cairo.

Peter, L.P. and Young, V.R. (1980) "Nutritional Evaluation of Protein Foods". p.8. The United Nations University, Japan.

Rady, M.S, Gomaa,A.A. and Nawar, A.A. (1981) Genotypic variability and correlation coeffecients in quantitative characters in a cross between Egyptian and Mexican wheats (Triticum aestivum L.). Minufiya J. Agric. Res. 45 (6), 211.

Salem, A.H., Rabie, H.A., Mohamed, M.A. and Salim, M.S. (1990) Association between grain yield and its contributing characters in some wheat genotypes as influenced by location and seeding rates. Proc. $4^{\text {th }}$ Conf. Agron. Cairo, 1, pp.89-97.

Shaaban, M. M. (2002) Effect of trace-nutrient foliar fertilizer on nutrient balance, growth, yield and yield components of two cereal crops. Pakistan J. Biological Sci., 7(4), 770-774.

Snedecor, G.W. and Cochran, W.G. (1967) "Statistical Methods", $6^{\text {th }}$ edition. Iowa State College, Ames, Iowa, U. S. A.

Voldeng, H.D. and Simpson, G.M. (1967) Leaf area as an indicator of potential grain yield in wheat. Canadian J. Plant Sci. 47, 359-365.

Waller, R.A. and Duncan, D.B. (1969) A bays rule for the symmetric multiple comparisons problem. American Stat. Associated J. December. 1485.

Zeidan, M.S. and Nofal, O.A. (2003) Effect of urea on the efficiency of spraying iron, manganese, zinc and copper on wheat. Egyptian J. Agron. 24, 121-131.

Ziaeian, A.H. and Malakouti, M.J. (2001) Effects of $\mathrm{Fe}, \mathrm{Mn}, \mathrm{Zn}$ and $\mathrm{Cu}$ fertilization on the yield and grain quality of wheat in the calcareous soils of Iran. Plant Nutrition Food security and sustainability of agro-ecosystem, 92, 840-841.

(Received 6/4/2011, accepted 4/8/2011) 


\title{
تأثير الإضافة الورقية بسلفات الماغنسيوم والنحاس علي القمح تحت ظروف الأراضي الرملية
}

\author{
المتولي عبدالله المتولي، سيد أحمد سفينة ، فؤاد السيد عبد الله" و سارة سيد

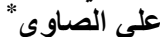 \\ قسم المحاصيل ـ كلية الزراعة - جامعة القاهرة وقسم تكنولوجيا التسميد - \\ "المركز القومى للبحوثـ الجيزة - مصر.
}

أجريت تجربتان حقليتان بمحطة التجارب الزراعية بالإسماعيلية لمركز البحوث

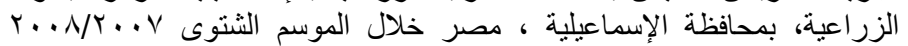

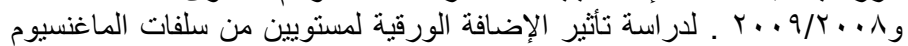

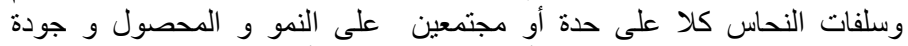

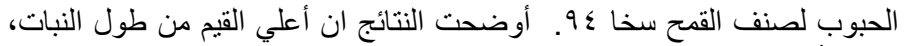

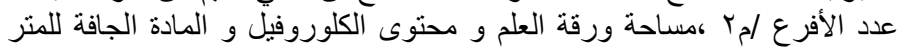

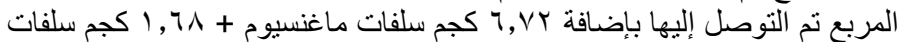

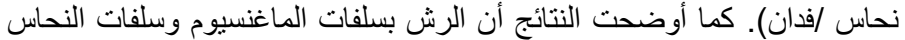

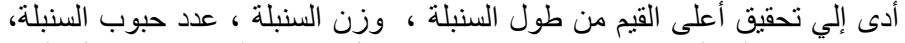

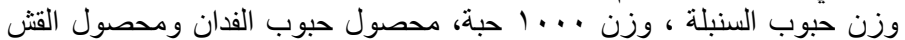

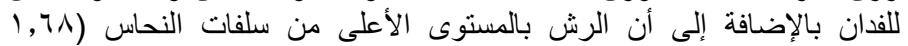

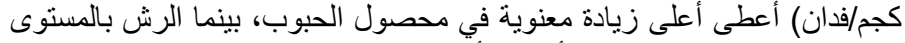

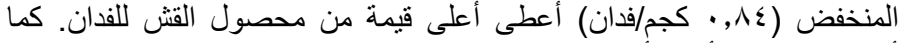

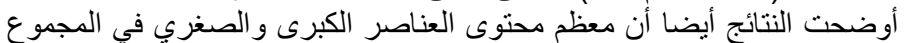

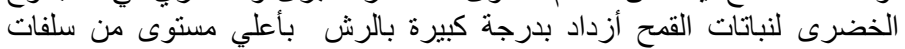

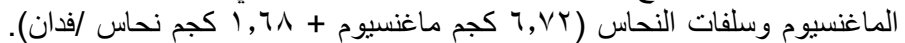

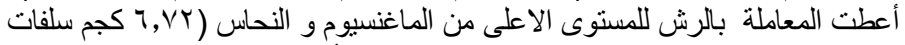

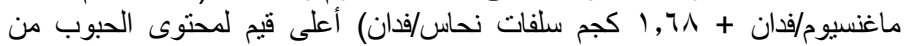

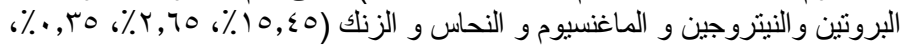

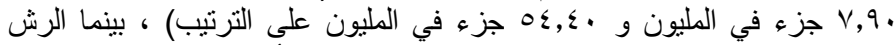

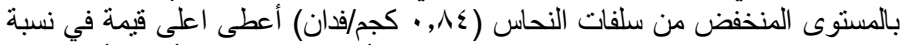

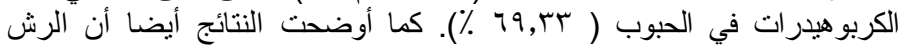

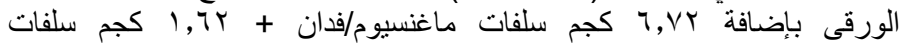

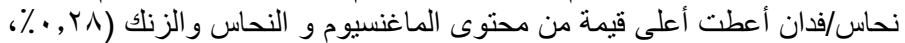

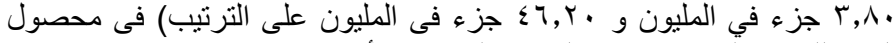

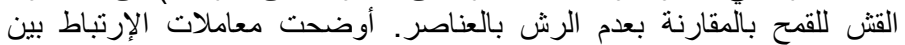

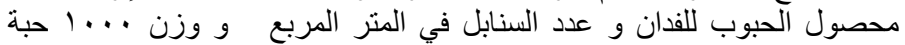

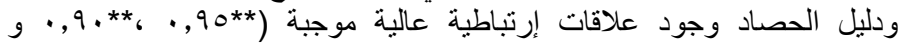

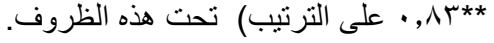

